\title{
Salinity effects on forage quality of Russian thistle
}

\author{
JAMES L. FOWLER, JAMES H. HAGEMAN, KENNETH J. MOORE, MARGARET \\ SUZUKIDA, HAMID ASSADIAN, AND MARIO VALENZUELA
}

\begin{abstract}
Authors are associate professor, Dep. Agronomy and Horticulture, New Mexico State Univ., Las Cruces 88003 professor, Dep. of Chemistry, New Mexico State Univ., Las Cruces 88003; research agronomist, USDA-ARS, Dep. of Agronomy, 336 Keim Hall, East, Univ. of Nebraska, Lincoln 68538; former research assistants, Dep. of Agronomy and Horticulture, New Mexico State Univ., Las Cruces 88003.
\end{abstract}

\begin{abstract}
Russian thistle (Salsola iberica Sennen and Pau), a common weed found on overgrazed rangelands, abandoned farmlands, and other disturbed sites in the western United States, is often grazed by livestock and in times of drought has been extensively harvested for hay. Much of the land where Russian thistle grows in the western United States has a salinity hazard. The purpose of this study was to determine the effects of salinity stress on forage quality of Russian thistle. Russian thistle plants were grown in a greenhouse in sand culture irrigated with salinized nutrient solutions (electrical conductivities of $1.3,10.6,19.5,26.8$, and 33.9 $\mathrm{dS} / \mathrm{m}$ ) prepared with $\mathrm{NaCl}$ and $\mathrm{CaCl}_{2}$ (2:1 molar ratio). Chemical indices of forage quality (total $\mathrm{N}$, neutral detergent fiber, acid detergent fiber, acid detergent lignin, nitrate, and oxalates) at 2 growth stages (early flower and full nower) were determined. Forage quality of Russian thistle, as measured by total $\mathbf{N}$ and fiber constituents, improved with increasing salinity. Mineral ash content increased with salinity stress at both growth stages but was reduced slightly by increasing maturity. Nitrate levels increased at early flower but decreased at full flower with increasing salinity, whereas oxalate levels at both growth stages were reduced by salinity. Neither component was of sufficient magnitude to be toxic to ruminants. These results indicate that salinity stress is not detrimental to forage quality of Russian thistle but tends to improve it.
\end{abstract}

Key Words: Salsola iberica, nitrogen content, neutral detergent fiber, acid detergent fiber and lignin, nitrate, water-soluble oxalates

\footnotetext{
Journal article 1573, N.M. Agr. Agr. Exp. Sta., Las Cruces.

Research was funded in part by the U.S. Dep. of the Interior, Geological Survey, through the New Mexico Water Resources Res. Inst., and in part by a grant from the New Mexico State Univ. Plant Genetic Engineering Lab. Authors wish to thank Dr.

L. Murray and Dr. M. Ortiz for assistance in statistical analyses.

Manuscript accepted 10 Mar. 1992.
}

Russian thistle (Salsola iberica Sennen and Pau), an introduced, annual, ruderal weed commonly found along fence rows, ditch banks, roadways, on abandoned farmland, and on overgrazed rangeland in much of the western United States, is often utilized as forage by livestock and is under study as a potential arid-lands forage crop. Studies of the chemical composition and digestibility of Russian thistle (Cave et al. 1936, Bell et al. 1954, Hageman et al. 1978, Hageman et al. 1988) and its utilization by livestock grazing western rangeland (Esplin et al. 1937, Cook et al. 1954, Nelson et al. 1970) support its potential as an arid-lands forage. The wateruse efficiency and drought tolerance of Russian thistle indicate that it is one of the most water-use-efficient species studied, yet capable of maintaining relatively high rates of forage production (Dillman 1931, Dwyer and Wolde-Yohannis 1972, Fowler and Hageman 1978). Recently, the first quantitative study of the salinity tolerance of Russian thistle was published (Fowler et al. 1988) verifying that it is also salt tolerant.

About $50 \%$ of the irrigated land in the western United States has a salinity hazard and crop production is limited by salinity on about $25 \%$ of these lands (Wadleigh 1968). Western rangelands are also affected by salinity, especially in basins and valleys with restricted drainage where salts have accumulated on or near the soil surface (Chapman 1975). Considering the large areas of cropland and rangeland affected by salinity in the western United States, it is surprising that so little information has been reported about the effects of salinity stress on forage quality. The objective of this investigation was to determine effects of salinity stress on chemical indices of forage quality of Russian thistle.

\section{Materials and Methods}

Russian thistle plants were grown in a greenhouse near Las Cruces, New Mexico, from seed of a plant selection typical of $S$. 
Table 1. Analyses of variance of forage quality properties of Russian thistle plants grown at 5 salinity levels and harvested at early flower (67 DAP) and full flower (91 DAP).

\begin{tabular}{|c|c|c|c|c|c|c|c|c|}
\hline Source & df & $\begin{array}{c}\text { Total } \\
\mathbf{N}\end{array}$ & $\begin{array}{l}\text { Neutral } \\
\text { detergent } \\
\text { fiber }\end{array}$ & $\begin{array}{l}\text { Acid } \\
\text { detergent } \\
\text { fiber }\end{array}$ & $\begin{array}{c}\text { Acid } \\
\text { detergent } \\
\text { lignin }\end{array}$ & Nitrate & $\begin{array}{l}\text { Water } \\
\text { soluble } \\
\text { oxalates }\end{array}$ & $\begin{array}{l}\text { Total } \\
\text { oxalates }\end{array}$ \\
\hline & \multicolumn{8}{|c|}{ Mean Squares } \\
\hline (Early flower) & & & & & & & & \\
\hline Salinity & 4 & $9.98 * *$ & $3,425^{*}$ & $381,843^{* *}$ & $3,583^{*}$ & 351 & $16,874^{* *}$ & 657 \\
\hline Linear & 1 & $36.49 * *$ & $13,301 * *$ & $1,433,134^{* *}$ & $11,004 * *$ & 946 & $39,905^{* *}$ & 2,080 \\
\hline Quadratic & 1 & 1.18 & 130 & 37,003 & 2,087 & 15 & $20,331^{* *}$ & 0 \\
\hline Cubic & 1 & 0.59 & 254 & 28,834 & 1,050 & 418 & $7,161^{*}$ & 112 \\
\hline Error & 12 & 1.18 & 870 & 27,037 & 934 & 301 & 862 & 1,604 \\
\hline $\mathrm{CV}, \%$ & & 3.63 & 7.38 & 8.25 & 9.32 & 32.48 & 13.15 & 4.71 \\
\hline \multicolumn{9}{|l|}{ (Full flower) } \\
\hline Salinity & 4 & $13.58^{* *}$ & $1,721^{*}$ & $3,583^{* *}$ & $73 * *$ & $117^{*}$ & $109.4^{* *}$ & 37 \\
\hline Linear & 1 & $45.16^{* *}$ & $6,700^{* *}$ & $13,802^{* *}$ & $246^{* *}$ & $318^{* *}$ & $248.8 *$ & 111 \\
\hline Quadratic & 1 & $7.38^{*}$ & 23 & 1 & 13 & 13 & $107.2^{* *}$ & 14 \\
\hline Cubic & 1 & 1.75 & 18 & 365 & 32 & 0 & $68.9^{\star}$ & 19 \\
\hline Error & 12 & 1.29 & 535 & 194 & 5 & 31 & 1.5 & 24 \\
\hline $\mathrm{CV}, \%$ & & 4.37 & 5.23 & 5.51 & 5.17 & 19.92 & 12.27 & 6.18 \\
\hline
\end{tabular}

*,**Significant at the 5 and $1 \%$ levels of probability, respectively.

iberica (Beatley 1973). Details of plant establishment, growing conditions, experimental design, salinity treatments, and plant sampling were reported previously (Fowler et al. 1988) under "Reproductive Stage". Briefly, Russian thistle plants were grown in pots in sand culture and irrigated with salinized nutrient solutions [electrical conductivities of treatment solutions $\left(\mathrm{EC}_{\mathrm{ta}}\right)$ of 1.3 , $10.6,19.5,26.8$, and $33.9 \mathrm{dS} / \mathrm{m}$ ]. Salinity treatments began at 42 days after planting (DAP) when the plants were in the transition between the vegetative and reproductive stages. Plants used for the forage quality determinations were harvested at 67 and 91 DAP by cutting the main stem near the sand surface in each pot. A total of 9 plants was harvested from 3 pots in each treatment and combined as 1 sample, dried in a forced-draft oven $\left(60\right.$ to $65^{\circ} \mathrm{C}$ for 48 to 72 hours), and ground to pass a $425-\mu \mathrm{m}$ screen. Samples were redried for 24 hours at 60 to $65^{\circ} \mathrm{C}$ and stored in screwcapped glass jars. A subsample of each ground sample was dried overnight at $105^{\circ}$ to determine dry matter content.

The plant material was analyzed for concentrations of total $\mathrm{N}$, neutral detergent fiber (NDF), acid detergent fiber (ADF), acid detergent lignin (ADL), nitrate, and oxalate. All chemical analysis values were calculated on an oven-dried basis. A slightly modified version of the AOAC method (AOAC 1980, p. 858) was used for total $\mathrm{N}$ determinations. The $0.2-\mathrm{g}$ samples were digested using circa $0.5 \mathrm{~g} \mathrm{Kel-pac}$ Powder No. 2 (Curtin Matheson Scientific, Houston, Tex.) and $4 \mathrm{ml}$ of $18 \mathrm{M} \mathrm{H}_{2} \mathrm{SO}_{4}$. Deionized $\mathrm{H}_{2} \mathrm{O}(20 \mathrm{ml})$ was added after digestion to dissolve solids. For distillation, a few grains of $\mathrm{Zn}$ dust and $20 \mathrm{ml}$ of $11.25 \mathrm{M} \mathrm{NaOH}$ were added. Circa $30 \mathrm{ml}$ of distillate was collected in a $0.47 \mathrm{M}$ boric acid solution containing methyl purple indicator and titrated to the end point with $0.1 \mathrm{M}$ $\mathrm{HCl}$. Total $\mathrm{N}$ assays were done in duplicate or triplicate. Concentrations of NDF, ADF, and ADL were determined on 1-g samples using methods described by Goering and Van Soest (1970). The procedure described by the AOAC (AOAC 1980) for determination of oxalates was modified slightly using procedures outlined by Baker (1952) to accommodate a dried plant sample, rather than a canned vegetable product, and to allow for the determination of water-soluble as well as total (soluble and insoluble) oxalates. Oxalates were determined on duplicate subsamples by titration with $0.02 \mathrm{M} \mathrm{KMnO}_{4}$. Results are expressed as grams oxalate as oxalic acid $/ \mathrm{kg}$ dry wt. Nitrates were determined by the procedure of Cataldo et al. (1975) without modification. All samples were analyzed in duplicate and expressed as $\mathrm{g} \mathrm{NO}_{3}^{-} / \mathrm{kg}$ dry wt.

All forage quality values were subjected to analysis of variance and effects were tested by orthogonal contrasts procedures (SAS 1985). These statistical data are given in Table 1. Quality determinations with significant $(P \leq 0.05)$ responses to salinity stress were fitted to response functions using regression techniques.

\section{Results and Discussion}

\section{Total Nitrogen and Cell Wall Components}

Total N concentration of Russian thistle linearly increased with increasing salinity stress at both early flower and full flower growth stages (Fig. 1). Nitrogen concentrations were lower at full flower than at early flower at comparable salinity levels. In contrast, Bell et al. (1954) observed a one-third reduction in $\mathrm{N}$ content (crude protein) of 6 range grasses growing on alklaline soils as compared

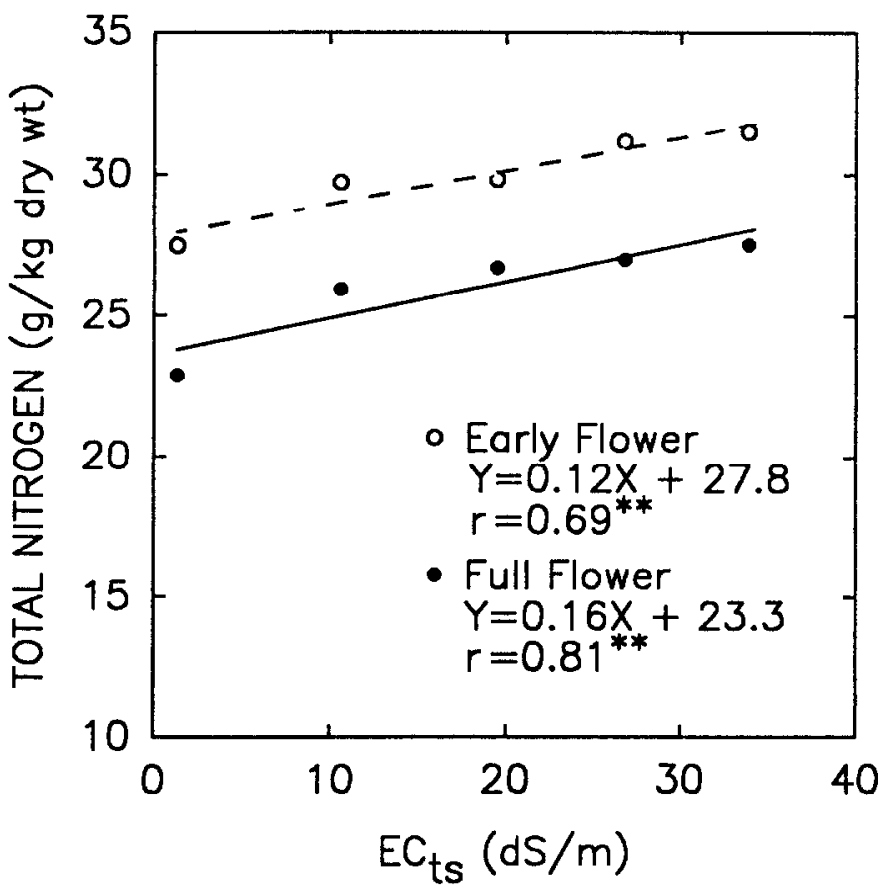

Fig. 1. Effect of salinity stress on the nitrogen concentration of Russian thistle at 2 growth stages, early flower and full fower. 
to that of the same grass species on nonalkaline soils; but alkalinity of soil had no effect on the $\mathrm{N}$ content of yellow sweet clover, a plant having some tolerance to alkaline soils. Hussain (1981) using highly saline irrigation water $(2.5$ to $8.0 \mathrm{dS} / \mathrm{m})$ found little effect of salinity on $\mathrm{N}$ content of a fodder barley (Hordeum vulgare L.) crop.

Neutral detergent fiber decreased linearly with increasing salinity at both early flower and full flower and was higher at each salinity level at the full flower stage of development than at early flower at comparable salinity levels (Fig. 2). As indicated by the slopes of the lines in Fig. 2, NDF concentration of plants at the

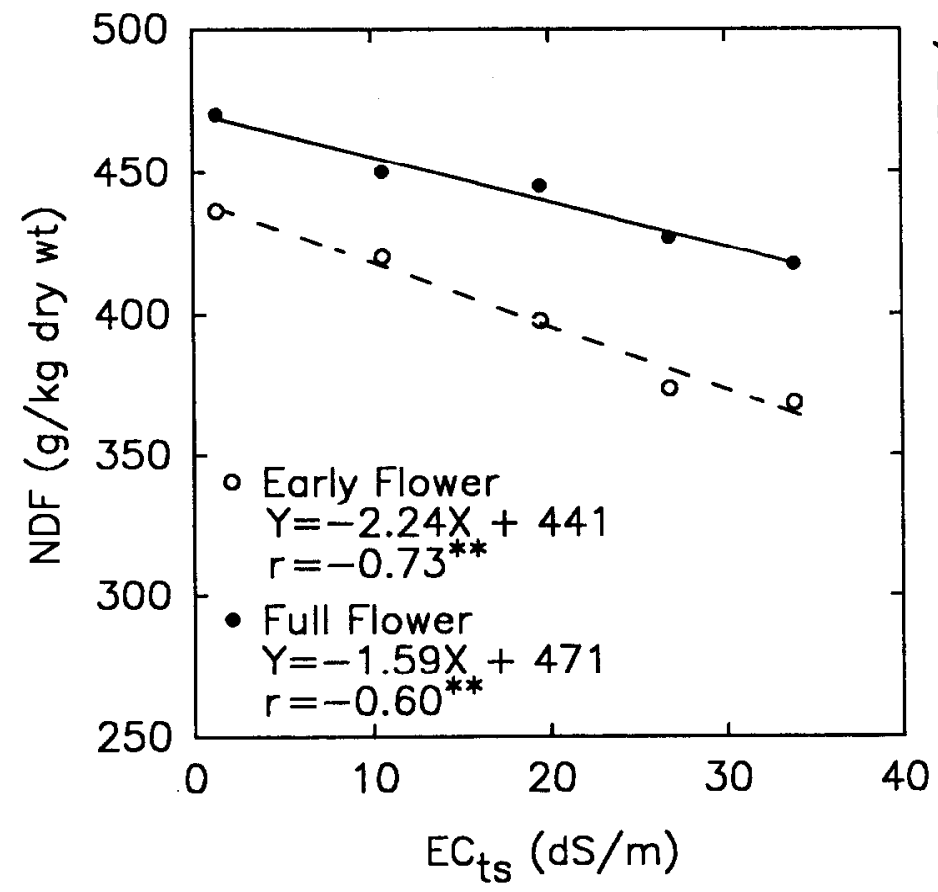

Fig. 2. Effect of salinity stress on the neutral detergent fiber (NDF) concentration of Russian thistle at 2 growth stages, early flower and full nower.

later stage of development (full flower) was slightly less responsive to salinity stress. Coefficients of determination $\left(r^{2}\right)$ of 0.53 and 0.36 for the early flower and full flower association of NDF's to salinity, respectively, suggest that 30 to $50 \%$ of the NDF variation of Russian thistle in this study could be accounted for by the salinity stress effects.

The ADF concentration of Russian thistle also decreased with increasing salinity stress and increased with increasing maturity (early flower to full flower) in a manner similar to that of NDF but with a greater decrease due to salinity at full flower (Fig. 3). The regression models at early flower and full flower, resulted in $r^{2}$ 's of 0.69 and 0.71 , respectively. Lignin (ADL) concentration also decreased with increasing salinity, decreasing more sharply in the more mature plants but increasing with increasing maturity from early flower to full flower (Fig. 4). Decreasing ADL in response to increasing salinity would be expected to positively affect forage quality.

Neutral detergent fiber, ADF, and ADL increased with plant maturity (from early flower to full flower). Salinity stress, however, reduced total cell wall concentration. In contrast, total $\mathbf{N}$ level decreased with stage of maturity but increased with salinity stress. These responses strongly suggest that salinity stress in Russian thistle may delay plant maturity, thereby improving digestibility.

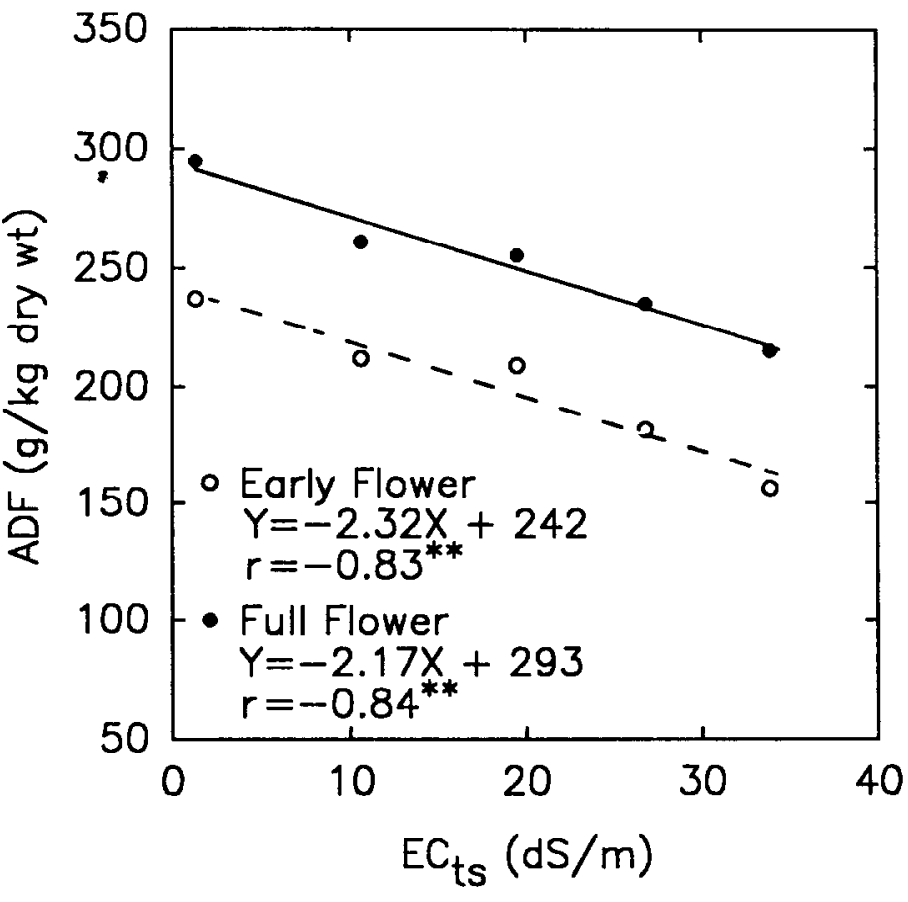

Fig. 3. Effect of salinity stress on the acid detergent niber (ADF) concentration of Russian thistle at $\mathbf{2}$ growth stages, early flower and full flower.

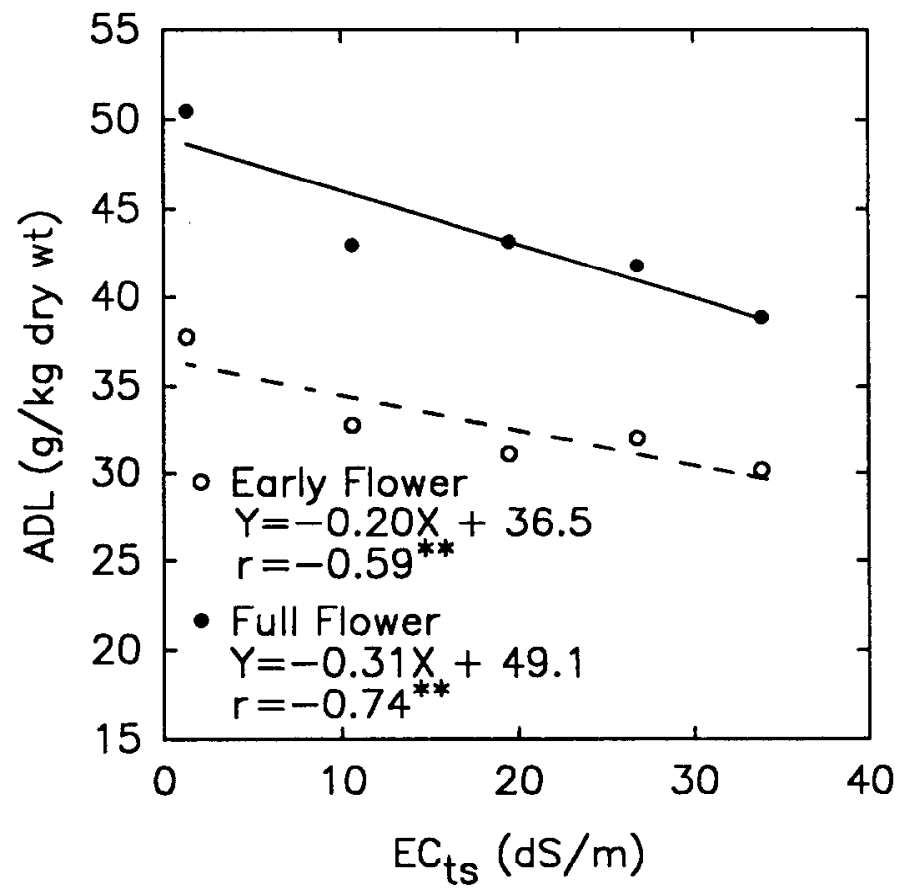

Fig. 4. Effect of salinity stress on the acid detergent lignin (ADL) concentration of Russian thistle at 2 growth stages, early flower and full nower.

\section{Mineral Ash Content}

Treatment means and statistical analyses of salinity stress effects on mineral ash levels and mineral ion composition of the ash from this experiment were reported and discussed in a previous paper (Fowler et al. 1988) in terms of ion accumulation and salt tolerance. Ash content increased with increasing salinity in both growth 
stages but was slightly lower at the later stage of maturity. The high ash content [175 to $254 \mathrm{~g} / \mathrm{kg}$ dry wt (Fowler et al., 1988)] of Russian thistle may account for the tendency of this forage to have a laxative effect which has been observed occasionally following extensive feeding on Russian thistle (Bell et al. 1954). Bell et al. (1954) attributed the laxative effect to excessive amounts of total ash $(219.7 \mathrm{~g} / \mathrm{kg}$ dry wt) and high levels of potassium $(37.3 \mathrm{~g} / \mathrm{kg}$ dry $w t)$, magnesium $(7.0 \mathrm{~g} / \mathrm{kg}$ dry $w t)$, and perhaps other mineral elements in the ash when Russian thistle constituted a major portion of the ration. In a feeding trial with dairy cattle comparing Russian thistle hay with an ash content of $156.5 \mathrm{~g} / \mathrm{kg}$ dry wt and alfalfa (Medicago sativa L.), no laxative effect was observed even when the diet consisted wholly of Russian thistle (Cave et al. 1936). Ash content ranged from 127 to $305 \mathrm{~g} / \mathrm{kg}$ dry wt in Russian thistle among 70 selections of Salsola grown under similar conditions in a nonsaline irrigated field experiment (Hageman et al. 1988). Whether the experiment is conducted in field soil or in sand culture using nutrient solution may also make a difference in ash content and the response of ash accumulation to salinity. Welch (1978) found no correlation between soil salinity and ash content in fourwing saltbush [Atriplex canescens (Pursh) Nutt.] under field conditions. Other studies with Atriplex species (Beadle et al. 1957, Ashby and Beadle 1957) showed differences in the correlations of ash content to salinity depending on whether the saltbush was growing in soil or nutrient solution. Where the saltbush was grown in soil, there was no close correlation between salinity and ash content; but when the saltbush was grown in nutrient solution, ash content increased as salinity increased.

\section{Potential Antinutritional Factors}

Both nitrates and oxalates are known to accumulate in some members of the Chenopodiaceae under certain conditions and can accumulate to levels toxic for livestock in some selections of Russian thistle under cultivation (Hageman et al. 1988). However, it was not known if salinity stress would alter the accumulation of these compounds in Russian thistle. Generally, both nitrates and oxalates tend to decrease with maturity in Russian thistle (Hageman et al. 1988). For this reason, nitrate levels and oxalate (total oxalate and water-soluble oxalate) levels as influenced by salinity stress and maturity were determined.

Increasing salinity had quite different effects on nitrate content of plants in the early flower growth stage compared to those in full flower (Fig. 5). Nitrates in plants at early flower were not significantly increased by salinity stress, but the mean nitrate content of $5.34 \mathrm{~g} / \mathrm{kg}$ dry wt exceeds the $5.00 \mathrm{~g}$ nitrate $/ \mathrm{kg}$ dry wt considered to be the threshold level of toxicity for livestock (Kingsbury 1964). However, cattle have been reported to graze, without ill effects, on forages containing an average of $20 \mathrm{~g}$ nitrate/ $\mathrm{kg}$ dry wt (Reid and James 1985). Nitrate toxicity is dependent on livestock liveweight as well as amount of nitrate consumed. At full flower, nitrate levels were lower than those at early flower, ranging from 3.34 to 2.26 $\mathrm{g} / \mathrm{kg}$ dry wt as salinity increased. Other researchers have reported declines in nitrate content associated with advancing plant maturity in several forage species (Crawford et al. 1961, Murphy and Smith 1967). Salinity stress, which appears to delay maturity, significantly reduced nitrate levels at the later stage of maturity. Drought stress may also delay maturity in forages (Wilson 1983) but tends to promote increased nitrate content (Kingsbury 1964). This suggests that some factor other than plant maturity is associated with the effect of salinity stress on nitrate accumulation during full flower in Russian thistle.

Total oxalate levels were not influenced by salinity stress at either harvest and were slightly lower at full flower $(80.1 \mathrm{~g} / \mathrm{kg}$ dry wt) than at early flower $(85.1 \mathrm{~g} / \mathrm{kg}$ dry wt.). Only water-soluble oxalates are considered to be a problem in livestock forage (Kingsbury 1964). Water-soluble oxalates were significantly reduced by

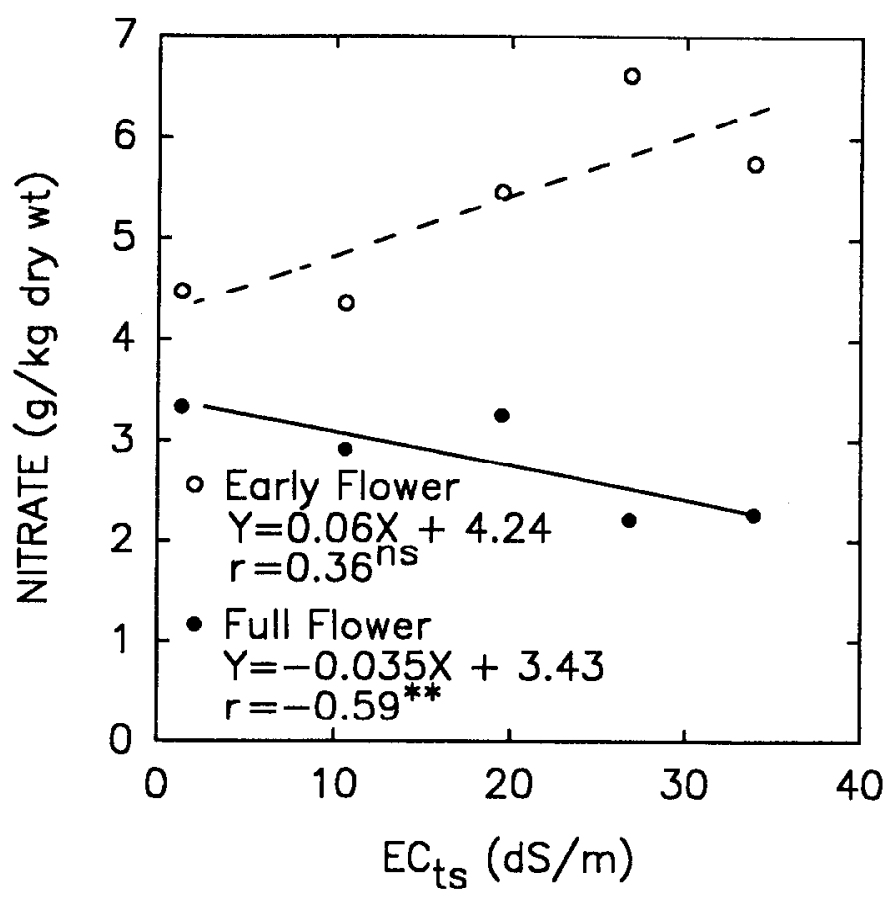

Fig. 5. Effect of salinity stress on the nitrate concentration of Russian thistle at 2 growth sites, early flower and full flower.

41 and $60 \%$ by a salinity stress of $10.6 \mathrm{dS} / \mathrm{m}$ at early flower and full flower, respectively, but no further decreases occurred at higher salinity levels (Fig. 6). The decreases in water-soluble oxalates are closely paralleled (on a molar basis) by increases in total $\mathrm{Ca}$ ion levels induced by salinity stress (Fowler et al. 1988), suggesting that the decreases in soluble oxalate concentrations with increasing salinity resulted from the formation of insoluble calcium oxalate.

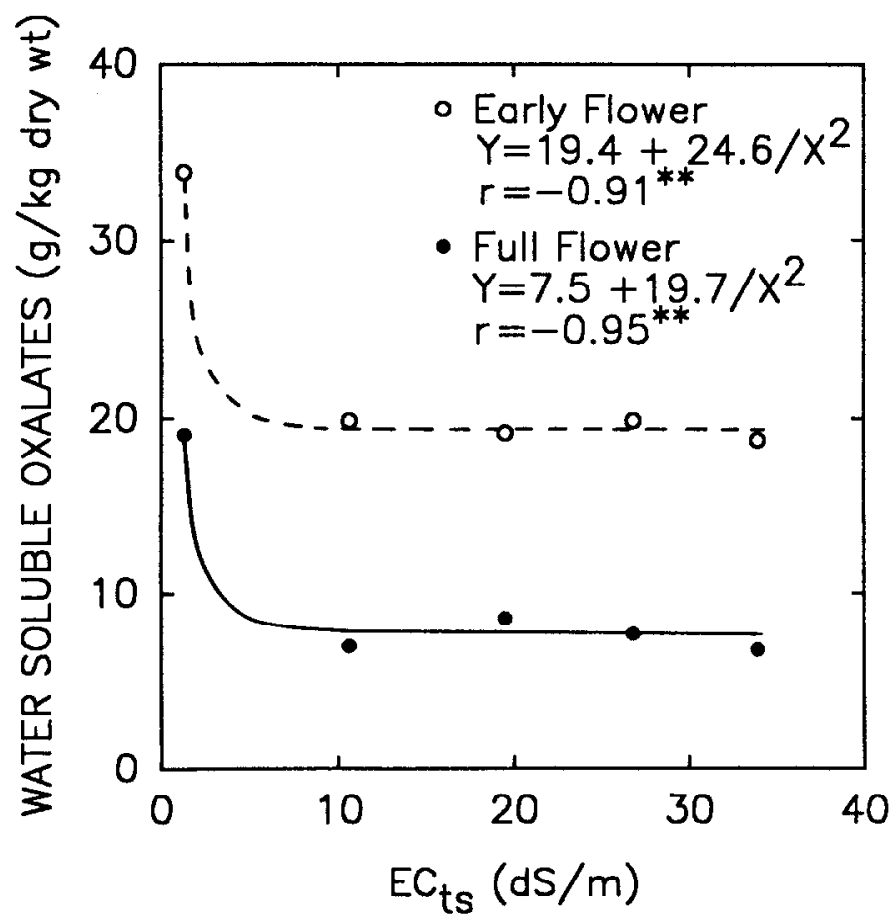

Fig. 6. Effect of salinity stress on the water soluble oxalate concentration of Russian thistle at 2 growth stages, early flower and full flower. 
No consistent level of toxicity for water-soluble oxalates has been established in ruminants. James et al. (1975) concluded that plants with soluble oxalate levels under $100 \mathrm{~g}$ oxalate $/ \mathrm{kg}$ dry wt are not toxic to ruminants but as Kingsbury (1964) points out, oxalate poisoning is complex and depends on a number of factors including the amount consumed, the time required for its consumption, and the presence of food in the stomach at the time of ingestion. Ruminants are more resistant to oxalate poisoning than nonruminants, partly because rumen bacteria in animals conditioned to oxalates can efficiently degrade oxalates in feed (Reid and James 1985). Calcium supplements will also reduce or eliminate oxalate toxicity when fed with high oxalate feeds (Kingsbury 1964).

\section{Conclusions}

Forage quality of Russian thistle, as measured by total $\mathrm{N}$ and fiber constituents, improved with increasing salinity stress. Many of the responses of Russian thistle to salinity stress observed in this study can be attributed, at least in part, to a delay in plant maturity. Potential negative factors (nitrate and water-soluble oxalates) decreased with increasing salinity stress for plants harvested at full flower; however, neither nitrate nor oxalate concentrations were of sufficient magnitude to be toxic to ruminant livestock. These results indicate that salinity stress is not detrimental to forage quality of Russian thistle, but enhances it, and demonstrate that Russian thistle has good forage potential for arid lands.

\section{Literature Cited}

Ashby, W.C., and N.C.W. Beadle. 1957. Studies in halophytes. III. Salinity factors in the growth of Australian saltbushes. Ecol. 38:344-352.

A.O.A.C. 1980. Official methods of analysis. 13th ed. AOAC, Washington, D.C.

Baker, C.J.L. 1952. The determination of oxalates in fresh plant material. Analyst 77:340-344.

Beadle, N.C.W., R.D.B. Whalley, and J.B. Gibson. 1957. Studies in halophytes. II. Analytic data on mineral constituents of these species of Atriplex and their accompanying soils in Australia. Ecol. 38:340-344.

Beatley, J.C. 1973. Russian-thistle (Salsola) species in western United States. J. Range Manage. 26:225-226.

Bell, J.M., P.D. McLaren, and G. McKay. 1954. Mineral and protein content of forage crops in central Saskatchewan. Can. J. Agr. Sci. $34: 252-262$.

Cataldo, D.A., M. Maroon, L.E. Schrader, and V.L. Youngs. 1975. Rapid colorometric determination of nitrate in plant tissue by nitration of salicylic acid. Comm. Soil Sci. and Plant Anal. 6:71-80.

Cave, H.W., W.H. Riddell, and J.S. Hughes. 1936. The digestibility and feeding values of Russian thistle hay. J. Dairy Sci. 19:285-290.

Chapman, V.J. 1975. The salinity problem in general, its importance, and distribution with special reference to natural halophytes, p. 7-24. In: A. Poljakoff-Mayber and J. Gale (eds.), Plants in saline environments. Springer-Verlag, N.Y.
Cook, C.W., L.A. Stoddart, and L.E. Harris. 1954. The nutritive value of winter range plants in the Great Basin. Utah Agr. Exp. Sta. Bull. 372.

Crawford, R.F., W.K. Kennedy, and W.C. Johnson. 1961. Some factors that affect nitrate accumulation in forages. Agron. J. 53:159-162.

Dillman, A.C. 1931. The water requirements of certain crop plants and weeds in the Northern Great Plains. J. Agr. Res. 42:187-238.

Dwyer, D.D., and K. Wolde-Yohannis. 1972. Germination, emergence, water use and production of Russian thistle. Agron. J. 64:52-55.

Esplin, A.C., J.E. Greaves, and L.A. Stoddart. 1937. A study of Utah's winter range. Composition of forage plants and use of supplements. Utah Exp. Sta. Bull. 277.

Fowler, J.L., and J.H. Hageman. 1978. Nitrogen fertilization of irrigated Russian-thistle forage. I. Yield and water use efficiency. Agron. J. 70:989-992.

Fowler, J.L., and J.H. Hageman, M. Suzukida, and H. Assadian. 1988. Evaluation of the salinity tolerance of Russian-thistle, a potential forage crop. Agron. J. 80:250-258.

Goering, H.K., and P.J. Van Soest. 1970. Forage fiber analysis: apparatus, reagents, procedures, and some applications. USDA-ARS Agr. Handb. 379.

Hageman, J.H., J.L. Fowler, and D.A. Schafer. 1978. Nitrogen fertilization of irrigated Russian-thistle forage. II. Some nutritional qualities. Agron. J. 70:992-995.

Hageman, J.H., J.L. Fowler, M. Suzukida, V. Salas, and R. LeCaptain. 1988. Analysis of Russian thistle (Salsola species) selections for factors affecting forage nutritional value. J. Range Manage. 41:155-158.

Hussain, Z. 1981. Using highly saline irrigation water for a fodder barley crop. J. Agr. Sci. (Camb.) 96:515-520.

James, L.F., M.J. Allison, and E.T. Littledike. 1975. Production and modification of toxic substances in the rumen. In: I.W. McDonald and A.C.I. Warner (eds.), Digestion and metabolism in the ruminant. Univ. New Zealand Publ. Unit, Armidale, Australia.

Kingsbury, J.M. 1964. Poisonous plants of the United States and Canada. Prentice-Hall, Inc., Englewood Cliffs, N.J.

Murphy, L.S., and G.E. Smith. 1967. Nitrate accumulations in forage crops. Agron. J. 59:171-174.

Nelson, A.B., C.H. Herbel, and H.M. Jackson. 1970. Chemical composition of forage species grazed by cattle on arid New Mexico range. New Mexico Agr. Exp. Sta. Bull. 561.

Reid, R.L., and L.F. James. 1985. Forage-animal disorders, p. 430-444. In: M.E. Heath, R.E. Barnes, and D.S. Metcalfe (eds.), Forages. The science of grassland agriculture. 4th ed. Iowa State Univ. Press, Ames.

SAS Institute. 1985. SAS user's guide. Statistics. 5th ed. SAS Inst., Inc. Cary, N.C.

Wadleigh, C.H. 1968. Wastes in relation to agriculture and forestry. USDA Misc. Pub. 1065. U.S. Gov. Print. Off., Washington, D.C.

Welch, B.L. 1978. Relationships of soil salinity, ash, and crude protein in Atriplex canescens. J. Range Manage. 31:132-133.

Wilson, J.R. 1983. Effects of water stress on herbage quality. p. 470-472. In: J.A. Smith and V.W. Mays (eds.), Proc. XIV Int. Grassland Cong., Lexington, Ky. 15-24 June 1981. West view Press, Inc., Boulder, Colo. 